\title{
Biological Quality of Soils for the Case of Ecuadorian Amazon
}

As is it known, soil is the basis of all activity in which man is involved. At the same time, it is the key factor for the development of the life and biodiversity of the planet's flora and fauna. Hence, as result of global warming and climate change, ecological research has recently increased its importance on the bases that extensive forest areas, act as carbon sinks mitigating greenhouse gas emissions. But no less important for investigation should be to inquire under this plant cover. Because there is a totally unimaginable and diverse world that remains in constant interactions to keep alive and from the green covering habitat to the diverse forms from small mammals to man. Man in its early days learned to manage the soil with the aim of producing food. Afterwards the exponential growth of the population was produced, and a high demand for food, caused the expansion of livestock borders, caused the devastation of large areas of forests, and generated a great impact to the soil and ecosystem. As a result, the change in land use and the application of chemicals impoverished and impairs the soil and the life that inhabits it. This is why this work highlights the importance of the biological component of soil to the context of the Amazon of Ecuador. For this reason, is important to consider different organisms as Essential Indicators of Soil Quality, mainly for the tropical soil field. In order to reach this objective, we compiled information presenting it in tables. They facilitate the interpretation of the importance of species of organisms and parameters from a biological point of view. At the same time, they can be used as a theoretical basis for the development of projects and research aimed to the management of biological soil composites.

\section{Quality Concept}

Soil, water, and air quality are the components of environmental quality, but if we focus explicitly on soil resources, the quality is more complex to define due to its variety of components $[\underline{1}]$, and the enormous amount of interrelationships between its components. Chemical, physical, and biological parameters can be analyzed and integrated to form a soil quality index that allows comparisons between different uses or management practices [2]. Soil quality is usually focused on agricultural production [ $\left.{ }^{3}\right]$, but is also a critical component in the maintenance of sustainability [4] , and human and environmental health [2]. A soil's quality is defined "as its ability to function within an ecosystem; to sustain or improve animal or plant productivity; to maintain and control environmental quality, and to support the habitability and health of man" $[\underline{5}]$.

The biological component is of great importance in assessing the management of land uses. This allows the implementation of agro-ecological management that favors agricultural production and biodiversity [4]. Some authors consider that for a soil to be considered high quality, it must meet criteria related to respiration, biomass, and its microbial activity []ㅡ, which correspond to biological parameters.

From a general point of view, the quality of the soils of the Ecuadorian Amazon is marked by fine clay textures, with good granular structure, on the surface horizon [7]. It has high $\mathrm{OM}$ content of low quality, low fertility, and acidic pH that limit the availability of nutrients, such as phosphorus and leaching of changeable bases (potassium, calcium, and

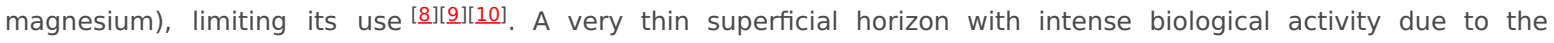
accumulation of OM, and the presence of humidity, influences biogeochemical behavior [11] : phosphorus deficiency, the

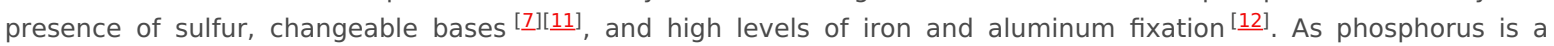
critical macronutrient $\left.{ }^{[13}\right]$, low levels of native phosphorus represent one of the biggest obstacles to food production. In general, the dark colors on the ground are associated with OM and high biological activity [10], and reddish colors are associated with ferric minerals [9][14]; a characteristic behavior of Amazonian soils.

Consequently, when talking about soil quality, the most important thing is to know if the focus is from the point of view of agricultural productivity, or environmental or human health. In addition, the quality can refer to the physical, chemical, or biological components of the soil. It is much more frequent that indicators are considered for the evaluation of the quality of the soil. In the context of the Amazon, biological indicators or bioindicators are very useful.

\section{Indicators}

An indicator is a parameter that allows for the verification of the soil's situation in relation to its state of conservation, pollution, productivity, or any other characteristic that provides information regarding its current and potential status [1][]ㅛㄷㅗ]. These indicators are classified into four categories: visual, physical, chemical, and biological indicators to assess the quality of a soil [4].

Visual indicators are obtained with field visits, farmers' perceptions, and local knowledge. These are based on observations and interpretations, such as the exposure of the subsoil, the color of the soil, the presence of gullies and weeds, the flooding, runoff, or poor vegetation development-all of these aspects are indications of alterations in soil quality [1][16][1]]. Physical indicators are related to the structure of the soil, as is the case for porosity, bulk density, penetration resistance, water retention capacity, hydraulic conductivity, aggregate size, depth, and texture. These mainly reflect the limitations of root growth, seedling sprouting, infiltration, or movement of water within the soil profile, transfer and cycling of nutrients []][1]6] . Chemical indicators include soil-plant properties, such as water quality 


\section{Encyclopedia}

and the availability of water, and nutrients for plants and microorganisms. Among the most common are $\mathrm{pH}$, electrical conductivity, organic matter content, cation exchange capacity, and nutrients (total N, total phosphorus and potassium) []][]ㅣ를.

Finally, biological indicators are related to the decomposition and incorporation of animal and plant residues in the soil by living organisms, controlling the supply of nutrients and humus to the ecosystem [18]. These indicators are based on soil respiration, microbial biomass, the amount of species and groups of edaphic fauna, as well as tests on enzymatic activities [19]. They act as early (microbiological and biochemical) signals of soil degradation or improvement due to their sensitivity [4][료. The close relationship of the quality of the soil with the functions developed by the edaphic life has made them valuable indicators of disturbance, based on both their functions and their diversity, density, and abundance ${ }^{[4]}$. When the indicator is a living being, it is called a biological indicator, or bioindicator.

\subsection{Biological Indicators (Bioindicators)}

An edaphic bioindicator is every living being that responds easily to external (soil) stimuli through changes at the organism level $\left[{ }^{6}\right]$. Bioindicators need to belong to large, diverse taxonomic groups, of wide geographical and ecological distribution [11][20]. They must be easy to handle, visible at any time of the year, with easy reproduction, and be abundant and preferably sedentary. Depending on the presence/absence of changes against these soil variations

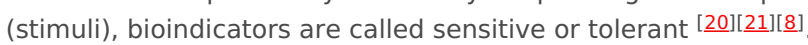

We present below the most representative organisms of soil biota, considered to be bioindicators, with a special focus on the context of the Ecuadorian Amazon. The information and descriptions as functions, characteristics, and functionalities of each group are summarized in the entry called "Soil Biology in the Ecuadorian Amazon" published for this same author. Table 1 shows the applicability of some more representative organisms as edaphic bioindicators, depending on their abundance or absence.

Table 1. Organisms used as edaphic bioindicators.

\section{Organisms of Soil Biota Considered Edaphic Bioindicators}

Organism

Earthworms

\section{Termites}

Snails and Slugs

\section{Centipedes and Millipedes}

\section{Enquitraeid worms}

\section{Indicator}

They are recognized for presenting sensitivity to anthropogenic disturbance, proposing them as indicators of soil degradation [22][23]. Several authors propose them as a biological indicator of the state of conservation/alteration of the soil according to the composition and abundance ${ }^{[20]}$. Their presence indicates preserved habitats $[\underline{24}]$.

They are considered excellent bioindicators to evaluate anthropogenic intervention due to the high sensitivity to environmental variations and deterioration of ecosystems

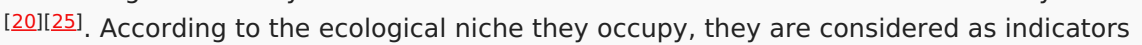
of the conservation status of the ecosystem []].

The presence of termites indicates less conserved habitats or habitats with a certain level of degradation, considered opportunistic organisms due to resistance to induced disturbances [20]. On the other hand, they are potentially the most important taxa as ecological indicators, because they are at the ecological center of many tropical ecosystems $[\underline{21]}$, and moreover, for their sensitivity to environmental or anthropogenic disturbances in biotic systems [26].

Used to indicate the state of disturbance in the edaphic environment, they are very sensitive to sudden changes in humidity and temperature, associated with vegetation cover and the entry of residues $[\underline{[20]}$. For this reason, they are considered indicators of humidity and temperature changes.

Used to indicate the state of disturbance in the edaphic environment, they are very sensitive to sudden changes in humidity and temperature, associated with vegetation cover and the entry of residues [20], and because these changes can influence its functions and abundance [2]․

They are drought-sensitive organisms [28]; for this reason they are considered drought indicators. They can be considered bioindicators of soil stability and fertility [29]. 


\section{Collembola}

Uropodinos

Astigmata

Mites

Gamasinos

Prostigmata

Nematodes

Protura, Diplura and Pauropoda

\section{Arbuscular mycorrhizal fungi}

\section{Algae}

Bacteria
Due to their action of reducing fungal concentrations, in crops they are used as bioindicators of soil contamination, since they have whitish and soft bodies, they are considered an indicator group of fertility and stability of the edaphic environment due to their sensitivity to chemical products and environmental disturbances [2ㅇ] . For the changes in their composition, they are considered indicators of ecological variations, due to the influence of agricultural practices, making the presence of taxa effective as bioindicators of herbicide treatment $[\underline{30]}$.

Due to their morphological and bioecological characteristics, they are very demanding in terms of habitat quality, suggesting them as potential bioindicators of disturbance, as they are sensitive to $\mathrm{OM}$ content, humidity, $\mathrm{pH}$, agricultural practices, use of insecticides, and environmental changes. They respond positively to good soil aeration conditions, considering them indicators of stable and productive soils, and in soils not intervened as bioindicators of low heavy metal values [2ㅇ] .

Surviving unfavorable environmental conditions, they are proposed as good indicators of disturbed soils [2의.

Biological indicators of soil stability and fertility; due to their susceptibility to environmental disturbances and the fragility of their whitish bodies, these characteristics also make them a good indicator of soil quality, since they are abundant in the least disturbed [29].

When they have high dominance, it is considered as an indicator group of the aridity and the imbalance of the edaphic communities is irreversible, because they have a high reproductive potential, which allows them to adapt to the disturbance and for this reason they are considered disturbance indicators [29].

They act as biological control agents for pests and insects, qualifying them as powerful bioindicators of ecological conditions [31]. Through appropriate analysis of the nematode community, the level of contaminant disturbance and changes in land use can be estimated ${ }^{[\underline{1}]}$, therefore, they are considered indicators of sensitivity and stability [32].

Due to their morphology and trophic functions, they are considered indicators, they are very sensitive to agricultural practices, thereby reducing their population [리].

The mycorrhizal association has recently been seen as an important indicator to assess soil quality. They also represent a key group of organisms in the soil that can affect plant productivity, biodiversity, and characteristics related to ecosystem sustainability [33]. Moreover, they are considered bioindicators of soils contaminated by heavy metals [34].

Excretions of fatty acids and carbohydrates, they stop erosion-forming aggregates [28]. Due to their nature and similar morphology, molecular techniques are used for better identification [35][36].

The actinomycetes in tropical soils are one of the most important bacterial groups [37], as indicated by a recent review of soil bacteria worldwide [38]. Their systematic classification is based on molecular techniques (16S rRNA sequencing) of soil

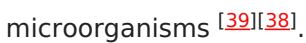

\subsection{Biological Quality Indicators}

These are parameters that serve to evaluate processes carried out by living beings in the soil, such as the transfer of nutrients from the soil to the plant, the dissolution of minerals that live in the mother rock, the mineralization of the OM, the stabilization of the soil structure that produces the OM, the cohesion of aggregates, and/or the formation of galleries that aerate and give porosity to the soil. As long as they can be measured, they can provide information on the condition and operation of the soil ${ }^{[4]}$. Table 2 summarizes the most important indicators, which we describe below.

Table 2. Biological quality indicators for Amazonian soils. 
Indicators

Methodology

Wet oxidation

method with

modified Walkley-

Modification of

physical

fractionation

Particulate organic
matter

Organic

Potentially

mineralizable

nitrogen

\section{Microbial biomass \\ Carbon of microbial biomass}

\section{Nitrogen from} microbial biomass

\section{Soil respiration}

Static incubation,

Alkali-trap method (Anderson 1982)

1970 Dewis and

Freitas Method

Method outlined

(Keeney and

Nelson 1982)

Modified Waring

and Bremner

Method (Keeney

1982)

Fumigation-

extraction method

with chloroform

(Jenkinson and

Powlson 1976)

Substrate-induced breathing method

(Anderson and

Domsch 1978)
Black dichromate

OM is considered an important indicator of soil quality and productivity [40], because it influences a wide range of soil properties. On the other hand, it is the most important component of soils, since it plays a key role in determining physical, chemical, and biological processes, exercising crop production [] . OM is a globally recognized variable as the universal indicator of soil quality [1요.

It is considered a sensitive indicator to changes due to soil management [34][4]] .

Both are positioned within the most sensitive indicators, helping to identify changes manifested at different depths and in the face of management practices [18]. Organic phosphorus allows the prediction of nutrient availability in the short term $[\underline{13}]$

It is a necessary indicator for a complete evaluation of the soil, it is associated with the quality of the OM. On the other hand, it corresponds to the amount of organic soil nitrogen that can be converted by microbial activity to soluble inorganic forms and due to its sensitivity it can be used as an indicator of the production capacity of the soil or as an indicator of the nitrogen contribution of the soil to support recommendations for the application of $\mathrm{N}^{[18]}$. Moreover, it is an indicator highly sensitive to changes in use in subtropical soils.

Microbial biomass is considered an indicator of soil fertility and quality, and is negatively affected by changes in land use and agricultural practices [니] . Furthermore, they are used as indicators of the first environmental changes by deforestation.

Microbiological parameters that have been used as indicators of the effect of agricultural practices and pollutants on soil quality [6], and as indicators of the relationship between biota and the restoration of degraded systems, allowing us to know the abundance and population structure of microorganisms [펴][르].

They have been proposed as indicators of soil quality in natural and agricultural systems, due to the role of microorganisms in the $\mathrm{C}, \mathrm{N}$ cycle [43], and their sensitivity [40]. In subtropical soils they can serve as potential biological indicators of ecological changes resulting from land use and management practices [녀] .

It is carried out by microorganisms under aerobic conditions, it is a useful index to know the amount of easily mineralizable substrate, by determining the amount of $\mathrm{CO}_{2}$ released by the action of biological activity and the easily mineralizable OC [ㅌ][토], allowing to evaluate the type of management to which a soil is subjected $[\underline{6}]$.

Indicator highly sensitive to changes in the use of subtropical soils [18].

Used as an indicator of soil quality and microbial activity, it can also indicate the amount of easily mineralizable substrates $\left.{ }^{[44}\right]$.

The metabolic processes that occur in the soil can serve as early and sensitive indicators against the changes caused by different soil management $[\underline{18}]$.

This quotient is a useful indicator to monitor changes in OM and is often used as a sensitive index to measure changes in soil OC. Its increase is considered as an indicator of environmental stress after the conversion of forests to farmland [피] .

Indicator of availability and quality of microbes, it is also sensitive to other factors, such as the proportion of fungal and bacterial biomass ${ }^{[44}$ ].

The stress of the microbial communities can be quantified by means of this parameter that reflects the energy requirement or indicates a change in the bacterial-fungal ratio. At the same time, it could be a useful parameter in the study of bioenergetic changes in developing ecosystems [45]. 


$\begin{array}{ll} & \begin{array}{l}\text { GMEa }=\text { (enzyme } x \\ \text { enzyme } \mathrm{x}\end{array} \\ \begin{array}{l}\text { Geometric } \\ \text { measurement of }\end{array} & \\ \text { enzymatic activity } & \begin{array}{l}\text { It consists of } \\ \text { (GMEa) }\end{array} \\ & \begin{array}{l}\text { multiplying the } \\ \text { values of each } \\ \text { enzymatic activity } \\ \text { to know GMEa. }\end{array}\end{array}$

\section{Molecular markers, quantitative and real-time PCR (polymerase chain reaction)}

Bead-beating

method
It is a measure of enzyme activity that is proposed as an indicator of recovery in the presence of bioavailable heavy metals [미].

It is an indicator of changes in soil quality under different agricultural management practices and is used to assess the effects of cultivation on soil quality [41]].

It has been shown to be a good index (condensing the set of enzyme values) to estimate the quality of the soil, since it is related to other physicochemical or biological properties of the soil. Furthermore, it is an early indicator of change in soil quality and is sensitive to metal contamination [녀].

The estimation by direct or indirect extraction of nucleic acids (DNA and RNA) from the soil and their subsequent study through molecular biology techniques, such as PCR, has been used successfully, and they have been proposed as indicators of microbial biomass activity [6]. This technique is capable of discriminating between bacterial and fungal biomass.

They are the preferred way to assess the structure and dynamics of the soil microbiological community, since microbiological life is a favorable indicator of adequate soil characteristics [4ㅌ].

They are considered as sensitive indicators between reforestation methods and changes produced by agricultural activity $[\underline{40]}$.

Due to their sensitivity, relationship with biological activity, and rapid response to changes that occur in the soil (use and management), they have been proposed as potential indicators of soil quality []][르]. Phosphatase activity is a soil indicator to estimate the potential mineralization of organic phosphate []].

Fluorogenically labeled substrates,

(Tabatabai 1982)
They are used as indicators of changes in soil microbial activity, in response to heavy metals and corrective measures $[\underline{[19]}$, and they show sensitivity to changes in land use and pollution.

They have been used as indicators of soil fertility and quality, but while being negatively affected by changes in land use and agricultural practices are proposed as indicators of soil degradation [41][44]. They can also indicate accelerated decomposition [44].

Organic matter (OM): the availability of OM is one of the main components of the soil. It is directly related to the different properties []][]ㅡ, such as the influence of temperature and humidity, which condition the mineralization in the microbial phase of the soil [므]

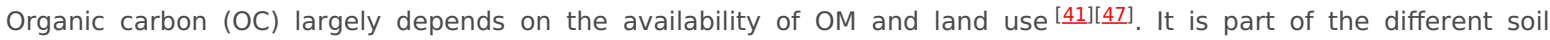
processes and is a source of food for edaphic organisms [47]. In pastures and crops, OC decreases by $65 \%$ compared to the forest [41], due to the low production of OM. It is among the five best carbon sinks $[\underline{6}]$.

Particulate organic matter refers to the youngest and most active portion of the OM. It is a reservoir of nutrients for the flora and fauna of the soil. It acts by increasing water carrying capacity and stabilizing aggregates. An analysis of this parameter allows the prediction of short-term nutrient availability [12][18].

Organic phosphorus is an important macronutrient for the functionality of plants. In tropical areas, availability limits

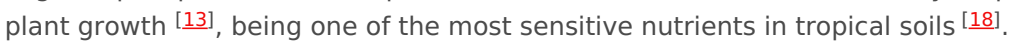

Potentially mineralizable nitrogen is the amount of organic $\mathrm{N}$ in the soil that is transformed into soluble inorganic forms, such as $\mathrm{NH}_{4}{ }^{+}$and $\mathrm{NO}_{3}{ }^{-}$, by microbial action. It is directly associated with the availability of OM and for its sensitivity it is considered as an indicator of nitrogen production or nitrogen contribution of a soil [1]ㅛ.

Microbial biomass (MB) is determined by the quantity and quality of OM that, at the same time, depends on the use of soil. Microbial characteristics are considered quality indicators [43]. Therefore, when MB is high, it indicates microbial diversity and an optimal environment. However, if they are at low levels, it is a sign of some kind of pollution [43] or due to changes in land use $[\underline{18}]$.

Carbon from microbial biomass (CMB) is related to the addition of OM to the soil. It indicates the biochemical and microbiological activity of soils. When it is high, it is considered an indicator of soil fertility [4ㄱ]. It provides knowledge on the abundance and population structure of microorganisms, and is obtained from the difference between samples with $C$ extracted and samples without $\mathrm{C}$ extracted ${ }^{[43]}$, according to the fumigation-extraction method with chloroform. CMB is considered an indicator of soil quality [ㅌ] $[\underline{41}]$. 
is obtained from the difference between fumigated ( $\mathrm{N}$ extracted) and non-fumigated samples [43], according to the method of fumigation-extraction with chloroform. Actual NMB scores, similarly to CMB, are determined by the conversion factor (mineralized fraction for $\mathrm{C}$ and $\mathrm{N}$ ) [느][43] , applied to the general formula that determines the MB.

Soil respiration refers to the production of $\mathrm{CO}_{2}$ as a result of microbial activity, roots, and macro and micro fauna. It is measured under anaerobic conditions and provides information on mineralizable substrates []. The larger the population, the greater the amount of $\mathrm{CO}_{2}$. It also relates to the size of plant waste, litter, and biota in general[18], considered as an index of biological activity.

Metabolic or microbial ratio is the index of the relationship between growth and state of latency of BM. It measures the microbial change of the soil with respect to environmental limitations due to changes in use. An increase indicates unfavorable conditions for soil microbes (microbial stress) [41]][45].

Geometric measurement of enzymatic activity (GMEa) is a common index to integrate data and information from

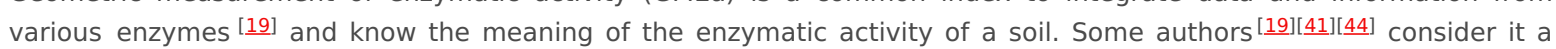
good index to estimate the quality of the soil. It can be related to physicochemical and biological properties.

Molecular markers-molecular techniques are capable of differentiating fungal microbial biomass, according to primers that are designed from the $16 \mathrm{~S}$ and $18 \mathrm{~S}$ rDNA genes $[\underline{6}]$. The genomic study of soils from DNA shows the genetic potential to produce certain enzymes, motivating the study of RNA. These techniques show real information on the state of the soil and the environmental conditions to which microorganisms are subjected [6][흐. The genome of bacteria provides signals when there is some kind of impact on the soil. Currently, the determination of indicators of soil quality is based on the DNA and RNA of the species of soil organisms. It has great potential, speed, and provides more informative measurements of biota $[\underline{1}]$.

Enzymatic activity: Table 5 synthesizes some types of enzymatic activity that can be evaluated in soil samples. Their activity is affected by the change of land use, especially in the surface layer []ㅡ. Low concentrations of enzyme activity indicate inactivity of microorganisms. High concentrations indicate the high decomposition of the OM and microbial activity [4ㄱ] . In tropical soils, the marked variations are probably due to acidity [47], which are considered land

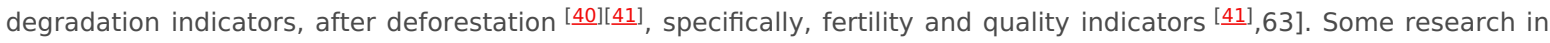
Amazonian soils considers that enzymatic activity indicates ecological changes resulting from land use [4그. According to [19], these activities (Table 3 ) are the most sensitive indicators to assess the effects of restoration practices and effects of land use change.

Table 3. Types of enzymatic activity that can be evaluated in soil samples.

\begin{tabular}{|c|c|c|c|}
\hline Enzyme & Substratum & Description & Author \\
\hline Dehydrogenase & $\begin{array}{l}2-p \text {-iodophenyl- } \\
3 p \text {-nitrophenyl- } \\
5 \text { tetrazolium } \\
\text { chloride }\end{array}$ & $\begin{array}{l}\text { Measures total oxidative activity of the microflora and } \\
\text { estimates the microbial activity. Indicates the redox } \\
\text { potential and oxidative capacity of the soil. It is } \\
\text { proposed as an indicator of microbial activity. Its } \\
\text { decrease may indicate the presence of herbicides. }\end{array}$ & {$[\underline{6}][\underline{40}]$} \\
\hline $\begin{array}{l}\text { O-diphenoloxi } \\
\text { dase }\end{array}$ & & $\begin{array}{l}\text { Catalyzes oxidation of phenolic compounds and } \\
\text { participates in the formation of humic substances. } \\
\text { Degrades recalcitrant organic compounds. }\end{array}$ & [] \\
\hline B-glucosidase & $\begin{array}{l}p \text {-nitrophenyl } B \text { - } \\
D \text {-glucosidase }\end{array}$ & $\begin{array}{l}\text { Catalyzes hydrolytic processes during the } \\
\text { decomposition of OM, the soil predominates, so it is } \\
\text { used to study the C cycle, as it degrades cellulose. } \\
\text { Indicates presence or absence of herbicides due to their } \\
\text { sensitivity. }\end{array}$ & {$[\underline{6}][\underline{19}][\underline{40}]$} \\
\hline $\begin{array}{l}\text { Acid and } \\
\text { alkaline } \\
\text { phosphatase }\end{array}$ & $\begin{array}{l}p \text {-nitrophenyl } \\
\text { phosphate }\end{array}$ & $\begin{array}{l}\text { Catalyzes the hydrolysis of organic esters, releasing } \\
\text { phosphate and phosphoric acid anhydrides, and is } \\
\text { considered an indicator of organic phosphate } \\
\text { mineralization. Related to the amount of available OM. }\end{array}$ & {$[\underline{6]}[\underline{19}][\underline{40}][\underline{41}][\underline{44}]$} \\
\hline Arylsulfatase & $\begin{array}{l}p \text {-nitrophenyl } \\
\text { sulfate }\end{array}$ & $\begin{array}{l}\text { Catalyzes hydrolysis of aromatic sulfate esters in } \\
\text { phenols and sulfate, is related to the amount of OM, } \\
\text { with greater activity in surface layers under natural } \\
\text { conditions. }\end{array}$ & {$[\underline{6}][\underline{19}][\underline{40}][\underline{41}][\underline{44}]$} \\
\hline
\end{tabular}


Ureasa urea use

Nitrogenase
Catalyzes the hydrolysis of non-peptide bonds, mineralizes $\mathrm{N}$ to $\mathrm{CO}_{2}$ and $\mathrm{NH}_{3}$, indicates losses of $\mathrm{N}$ in [ㅎ][19] the form of ammonia.

Participates in the reduction of nitrogen gas to ammonia and acetylene to ethylene (rapid sensitivity), measures nitrogenase activity, detects $\mathrm{N}$ fixatives (new [48] symbiosis).

\section{Minimum Number of Indicators}

In many cases, the limiting factor for measuring the soil quality through indicators is the cost, especially if biological parameters are included. Therefore, the total indicators contemplated to analyze the quality of the soil, at the initiative of several researchers, should be reduced to a minimum set of data [1].

The number of selected indicators usually varies between six and eight, and those that show the most relevant variations are chosen ${ }^{[1]}$. The selection and validation depends on the sensitivity and response to climatic changes, as well as their accessibility (sampling) [34]. The objectives of the investigation are also considered in selecting indicators [1].

The criterion for the selection of biological quality indicators is the score awarded by recognized researchers, frequency of use, reproducibility (essential aspect), and topicality in publications [1]]. Under the reference a possible set of indicators applicable to the soil context of the Ecuadorian Amazon is proposed in Table 4.

Table 4. Example of a minimum number of indicators of soil biological quality. Source: [ ${ }^{1]}$.

\begin{tabular}{|c|c|c|c|}
\hline Level & Indicator & Methodology & Principal Functions \\
\hline \multirow{7}{*}{$\begin{array}{l}\text { Population } \\
\text { and } \\
\text { community }\end{array}$} & $\begin{array}{l}\text { Presence, richness, and } \\
\text { abundance of individual } \\
\text { soil organisms }\end{array}$ & $\begin{array}{l}\text { Traditional methods, } \\
\text { microscopic, } \\
\text { molecular techniques. }\end{array}$ & $\begin{array}{l}\text { Cycle of OM and water, } \\
\text { soil structure, } \\
\text { regulation of } \\
\text { microorganisms }\end{array}$ \\
\hline & $\begin{array}{l}\text { Microbial and fungal } \\
\text { biomass }\end{array}$ & $\begin{array}{l}\text { Plate count, } \\
\text { fumigation, and } \\
\text { extraction with } \\
\text { chloroform }\end{array}$ & $\begin{array}{l}\text { Cycling of OM and } \\
\text { elements, soil } \\
\text { structure, } \\
\text { decomposition }\end{array}$ \\
\hline & $\begin{array}{l}\text { Indices based on soil } \\
\text { biota communities }\end{array}$ & $\begin{array}{l}\text { Identification and } \\
\text { counting of the } \\
\text { groups of organisms }\end{array}$ & $\begin{array}{l}\text { Cycle of OM and } \\
\text { elements, regulation of } \\
\text { biological population, } \\
\text { decomposition }\end{array}$ \\
\hline & $\begin{array}{l}\text { Community } \\
\text { composition }\end{array}$ & $\begin{array}{l}\text { Taxonomic } \\
\text { identification and } \\
\text { counting manual }\end{array}$ & $\begin{array}{l}\text { Cycle of OM and } \\
\text { elements, regulation of } \\
\text { biological population, } \\
\text { decomposition }\end{array}$ \\
\hline & $\begin{array}{l}\text { Soil respiration, } \\
\text { nitrification, and } \\
\text { denitrification }\end{array}$ & $\begin{array}{l}\text { Evolution of } \mathrm{CO}_{2} \text {, } \\
\text { emission of } \mathrm{N}_{2} \mathrm{O} \text {, and } \\
\text { production of } \mathrm{NO}_{3}\end{array}$ & $\begin{array}{l}\text { OM and water cycling, } \\
\text { decomposition, habitat } \\
\text { provision }\end{array}$ \\
\hline & $\begin{array}{l}\text { Potentially } \\
\text { mineralizable nitrogen }\end{array}$ & Anaerobic incubation & Natural fertilization \\
\hline & $\begin{array}{l}\text { Metabolic or microbial } \\
\text { ratio }\end{array}$ & & \\
\hline Ecosystem & $\begin{array}{l}\text { DNA and protein } \\
\text { synthesis }\end{array}$ & $\begin{array}{l}\text { Incorporation of } \\
\text { thymine and leucine } \\
\text { into DNA }\end{array}$ & \\
\hline
\end{tabular}




\begin{tabular}{|c|c|c|}
\hline Enzymatic activity & $\begin{array}{l}\text { Extraction and } \\
\text { incubation of soil } \\
\text { enzymes in various } \\
\text { substrates }\end{array}$ & $\begin{array}{l}\text { OM cycling, biological } \\
\text { population regulation, } \\
\text { decomposition }\end{array}$ \\
\hline $\begin{array}{l}\text { Metabolomics and } \\
\text { metaproteomics }\end{array}$ & $\begin{array}{l}\text { Evaluation and } \\
\text { quantification of } \\
\text { metabolites and } \\
\text { proteins in the soil }\end{array}$ & $\begin{array}{l}\text { OM cycling, regulation } \\
\text { of the biological } \\
\text { population, soil } \\
\text { structure, } \\
\text { decomposition. }\end{array}$ \\
\hline
\end{tabular}

\section{Field Indicators}

A project at the European level has developed simple and easy-to-use tools for farmers. The GROW Observatory project aims to provide services to citizens and non-profit science [49]. On the one hand, it allows for the measuring of soil parameters at high spatial resolution in large geographic areas. However, it has also opted for visual evaluations of soil in the field, a technique that is being implemented worldwide and is considered sensitive enough to assess the structure of a soil $\underline{[14]}$. Most of the methods are based on observations of soil structure, and its relationship with crop productivity [49]. Other authors have affirmed that the visual evaluation of the soil is not sufficient to determine its state, the state of an ecosystem, or the services it provides $[\underline{1}]$. They suggest that the indicators be preferably quantitative variables and propose the use of qualitative variables as valid and useful when there is no quantitative information, or when the costs of quantifiable parameters are high ${ }^{[4]}$.

Studies in tropical soils of Venezuela have shown a strong relationship between visual evaluation scores, physical properties, and soil quality indicators measured in the laboratory ${ }^{[14]}$. Some variables taken into consideration in the visual evaluation are: (a) texture (tape method); (b) structure, by direct macromorphological observation and using a reference table (granular, laminar, or blocose); (c) depth of horizon (measured in the field); (d) color (Munsell table); (e) soil erosion (presence or absence of grooves); (f) slope (clinometer); and (g) height (GPS). Some authors have also proposed texture as an observable parameter in the field [11][이][1]. To understand the variation and to be able to relate the scores of the variables, they adjusted the data to a common numerical scale, facilitating interpretation.

However, the guiding approaches that are still provided by farmers or people who work the land strengthen knowledge through on-site practice (real time) []. They have the ability to measure the status of any agency or community. They manage to hold a discussion with researchers, relating practice to theory [1] [34]. For example, the health of the soil can be determined from observations in the soil, plants, presence of animals, and water quality, and then related to laboratory analysis.

\section{Relational Indicators Integrated Index}

A correct evaluation of the soils takes into account the behavior and functionality of the organisms that inhabit it. Morphology, seasonality, and degree of sensitivity are also part of the evaluation process ${ }^{[29]}$, showing the state of the soil. Some examples of relational indicators are shown in Table 5; they indicate sensitivity or adaptability depending on their densities.

Table 5. Examples of relational indicators.

Relational Indicators

(Ratio)

Oribatidos/Astigmados

Oribatidos/Prostigmados
Description

Allows the prediction and evaluation of the degree of disturbance caused by the change of use in the ground. Based on densities (population), it expresses the ecological state of the edaphic environment and allows for the inference of the integral functioning of the ecosystem. Domination of astigmados indicates that the medium is altered and unstable.

Allow the evaluation of disturbances and state of the edaphic environment, like the previous relationship. If there is a dominance of prostitutes (indicator of aridity), the imbalance of soil communities is irreversible.

\section{Author}




\section{Mite/Collembola}

Earthworms/Termites

CMB and NMB/COT and NT

MB/Enzymatic activities

Soil respiration/CMB

\section{GMEa/nematode functionality ratio}

\section{$\mathbf{C} / \mathbf{N}$}

\section{Particulate OM/OM}

\section{Particulate OM/soil respiration}

Potentially mineralizable $\mathrm{N} /$ soil respiration
Useful for determining the degree of disturbance. If the density of collembola is greater, it indicates fertility and stability of the soil (conserved ecosystem), whereas if there are mites, it would be necessary to identify the dominant group and the function in the ground. This relationship expresses the ecological state of the edaphic environment.

Earthworm dominance means conserved habitats, and termite prevalence means less conserved habitats, as they are considered opportunistic and resistant to induced disturbances.

Reflect that the MB is determined by the quantity and quality of the OM. An increase or decrease in the content of microbial $C$ and $\mathrm{N}$, will depend specifically on soil management.

In wooded soils, they indicate inactivity of microorganisms due to limited availability of $\mathrm{C}$ and $\mathrm{N}$. This is with the exception of acid phosphatase.

Indicates the proportion of turnover and importance of $\mathrm{OC}$ in the soil for a general improvement.

Is a clear indicator of changes in soil quality, demonstrating sensitivity to heavy metals.

Low values of $\mathrm{N}$ indicate low quality humus. The presence of lignins and phenols may decrease the amount of $\mathrm{C}$.

If it is positive, it is considered an important indicator of the rate of decomposition.

Related to OM cycling and nutrient availability. It shows the relationship between $\mathrm{N}$ mineralization capacity, quality of plant residues, and soil respiration.

Is related to disturbance and acidity of the soil that favors fungal growth. It shows the relationship between OM, N mineralizable potential, and edaphic respiration. 
4. Vallejo Quintero, V.E. Importancia y utilidad de la evaluación de la calidad de suelos a través del componentemicrobiano: Experiencias en sistemas silvopastoriles. Colomb. For. 2013, 16, 83-99.

5. Doran, J.W.; Parkin, T.B. Defining Soil Quality for Sustainable Environment; Soil Science Society of America:Madison, WI, USA, 1994; ISBN 0-89118-807-X.

6. Cañizares-Gonzales, R. Potencial para el Secuestro de Carbono y la protección de la biodiversidad bacterianade prácticas agrícolas sostenibles en suelos de Olivar. In Diseño y Aplicación de Tecnologías “Ómicas”;Universidad de Granada: Granada, España, 2011.

7. Bravo, C.; Ramírez, A.; Marín, H.; Torres, B.; Alemán, R.; Torres, R.; Navarrete, H.; Changoluisa, D. Factoresasociados a la fertilidad del suelo en diferentes usos de la tierra de la Región Amazónica Ecuatoriana. Rev.Electron. Vet. 2017, 18, 1-16.

8. Tapia-Báez, R.G. Diversidad de Escarabajos Copronecrófagos y Estado de Consevación de la Microcuenca del RíoPindo; Universisdad Tecnológica Equinoccial: Quito, Ecuador, 2015.

9. Custode, E.; Sourdat, M. Paisajes y suelos de la Amazonia ecuatoriana: Entre la conservaci6n y la explotaci6n.Cultura 1986, 24, 325339.

10. Gardi, C.; Angelini, M.; Barceló, S.; Comerma, J.; Cruz-Gaistardo, C.; Encina-Rojas, A.; Jones, A.; Krasilnikov, P.;Mendonça-Santos, M.L.; Montanarella, L.; et al. Atlas de Suelos de América Latina y el Caribe, ComisiónEuropea-Oficina de Publicaciones de la Union Europea, L2995; Comisión Europea: Luxembourg, 2014; ISBN978-92-79-25599-1

11. Bravo, C.; Benítez, D.; Vargas Burgos, J.; Alemán, R.; Torres, B.; Marín, H. Caracterización socio-ambientalde unidades de producción agropecuaria en la Región Amazónica Ecuatoriana: Caso Pastaza y Napo. Rev.Amaz. Cienc. Y Tecnol. 2015, 4, 3-31.

12. Simpson, R.J.; Stefanski, A.; Marshall, D.J.; Moore, A.D.; Richardson, A.E. Management of soil phosphorusfertility determines the phosphorus budget of a temperate grazing system and is the key to improvingphosphorus efficiency. Agric. Ecosyst. Environ. 2015, 212, 263-277.

13. Bagyaraj, J.D.; Stürmer, S.L. Hongos micorrizógenos arbusculares (HMA). In Manual de Biología de SuelosTropicales; Instituto Nacional de Ecología: México city, Mexico, 2012; pp. 217-242.

14. Bravo, C.; Torres, B.; Alemán, R.; Marín, H.; Durazno, G.; Navarrete, H.; Gutiérrez, E.T.; Tapia, A. Indicadoresmorfológicos y estructurales de calidad y potencial de erosión del suelo bajo diferentes usos de la tierra en laAmazonía ecuatoriana. An. Geogr. Univ. Complut. 2017, 37, 247-264

15. Bonilla, C.; Gómez, E.; Sánchez, M. El Suelo: Los Organismos Que lo Habitan; Universidad Nacional deColombia: Palmira, Colombia, 2002; Volume 5.

16. Navarrete Segueda, A.; Vela Correa, G.; Lopez, J.; Rodriguez, M.D.L. Naturaleza y utilidad de los indicadoresde calidad del suelo. Contactos 2011, 80, 29-37

17. Pulido Moncada, M.; Gabriels, D.; Lobo, D.; Rey, J.C.; Cornelis, W.M. Visual field assessment of soil structuralquality in tropical soils. Soil Tillage Res. 2014, 139, 8-18.

18. Toledo, D.M.; Arzuaga, S.A.; Galantini, J.A.; Vazquez, S. Indicadores e Índices biológicos de calidad de sueloen sistemas forestales. Cienc. del Suelo 2018, 36, 1-12

19. Hinojosa, M.B.; García-Ruíz, R.; Benjamín, V.; Carreira, J.A. Microbiological rates and enzyme activitiesas indicators of functionality Ilar toxic spill in soils affected by the Aznalco. Soil Biol. Biochem. 2004, 36,1637-1644

20. Carey, J.C.; Fulweiler, R.W. The terrestrial silica pump. PLoS ONE 2012, 7, e52

21. Jones, D.T.; Eggleton, P. Sampling termite assemblages in tropical forests: Testing a rapid biodiversityassessment protocol. J. Appl. Ecol. 2000, 37, 191-203

22. Moreira, F.M.S.; Huising, J.E.; Bignell, D.E. Manual de Biologia de Suelos Tropicales: Muestreo y Caracterizacion dela Biodiversidad Bajo Suelo; Instituto Nacional de Ecologiía: México city, Mexico, 2012; ISBN 9786077908319.

23. González, G.; Zou, X.; Borges, S. Earthworm abundance and species composition in abandoned tropicalcroplands: Comparisons of tree plantations and secondary forests. Pedobiologia (Jena) 1996, 40, 385-391.

24. Lavelle, P.; Dangerfield, M.; Fragoso, C.; Eschenbrenner, V.; Lopez-Hernandez, D.; Pashanasi, B.; Brussaard, L.The relationship between soil macrofauna and tropical soil fertility. In The Biological Management of TropicalSoil Fertility; Woomer, P.L., Swift, M.J., Eds.; Wiley: Chichester, UK, 1994; pp. 137-169.

25. Bravo, C.; Torres, B.; Alemán, R.; Changoluisa, D.; Marín, H.; Reyes, H.; Navarrete, H. Soil structure andcarbon sequestration as ecosystem services under different land uses in the Ecuadorian Amazon Region.MOL2NET 2017, 3, 1-8

26. Enagbonma, B.J.; Babalola, O.O. Environmental sustainability: A review of termite mound soil material andits bacteria. Sustainability 2019, 11, 3847

27. Cabrera, G.; Robaina, N.; Ponce de Leon, D. Composicion funcional de la macrofauna edafica en cuatro usosde la tierra en las provincias de Artemisa y Mayabeque, Cuba. Pastos Y Forrajes 2011, 34, 313-330

28. Coyne, M. Microbiología del Suelo: Un Enfoque Exploratorio; Paraninfo: Madrid, Spain, 2000; ISBN 84-283-2648-7.

29. Socarrás, A. Mesofauna edáfica: Indicador biológico de la calidad del suelo. Pastos Y Forrajes 2013, 36, 5-13

30. Cole, L.; Bradford, M.A.; Shaw, P.J.A.; Bardgett, R.D. The abundance, richness and functional role of soilmeso- and macrofauna in temperate grassland-A case study. Appl. Soil Ecol. 2006, 33, 186-198.

31. Cares, J.E.; Huang, S.P. Nematodos del Suelo. Man. Biol. Suelos Trop. 2012, 5, 163-176.

32. Traunspurger, W.; Reiff, N.; Krashevska, V.; Majdi, N.; Scheu, S. Diversity and distribution of soilmicro-invertebrates across an altitudinal gradient in a tropical montane rainforest of Ecuador, with focus onfree- living nematodes. Pedobiol. J. Soil Ecol. 2017, 62, 28-35

33. Ruiz, P.; Rojas, K.; Sieverding, E. La distribución geográfica de los hongos de micorriza arbuscular: Unaprioridad de investigación en la Amazonía peruana. Espac. Y Desarro. 2011, 23, 47-63.

34. Ahmad-Wani, S.; Ahmad-Wani, M.; Ahmad-Sheikh, A.; Chand, S. Microbiological-Indicators with potentialfor evaluating soil quality. Int. J. Curr. Microbiol. Appl. Sci. 2017, 6, 831-839.

35. Hallmann, C. Biodiversity of Terrestrial Algal Communities from Soil and Air-Exposed Substrates Using aMolecular Approach. Ph.D. Thesis, Georg-August-University School of Science, Gottinghem, Germany, 2015.

36. Bérard, A.; Dorigo, U.; Humbert, J.F.; Martin-Laurent, F. Microalgae community structure analysis based on18S rDNA amplification from DNA extracted directly from soil as a potential soil bioindicator. Agronomie2005, 25, 285-291.

37. . Pfenning, L.H.; Abreu, L.M. Hongos del suelo saprófitos y patógenos de plantas. In Manual de Biología de SuelosTropicales; Instituto Nacional de Ecologí́a: México city, Mexico, 2000; pp. 243-280. ISBN 978-607-790-831-9.

38. Delgado-Baquerizo, M.; Oliverio, A.M.; Brewer, T.E.; Benavent-González, A.; Eldridge, D.J.; Bardgett, R.D.;Maestre, F.T.; Singh, B.K.; Fierer, N. A global atlas of the dominant bacteria found in soil. Science 2018, 359,320-325

39. . Corrales Morales, M.; Villalobos, K.; Rodríguez Rodríguez, A.; Muñoz Simón, N.; Umaña-Castro, R.Identificación y caracterización molecular de cianobacterias tropicales de los géneros Nostoc, Calothrix,Tolypothrix y Scytonema (Nostocales: Nostocaceae), con posible potencial biotecnológico. UNED Res. J.2017, 9, 280-288.

40. Izquierdo, I.; Caravaca, F.; Alguacil, M.M.; Roldan, A. Changes in physical and biological soil qualityindicators in a tropical crop system (Havana, Cuba) in response to different agroecological managementpractices. Environ. Manag. 2003, 32, 639-645.

41. Raiesi, F.; Beheshti, A. Microbiological indicators of soil quality and degradation following conversion ofnative forests to continuous 
croplands. Ecol. Indic. 2015, 50, 173-185.

42. Vance, E.D.; Brookes, P.C.; Jenkinson, D.S. An extraction method for measuring soil microbial biomass carbon.Soil Biol. Biochem. 1987, 19, 703-707.

43. Maharjan, M.; Sanaullah, M.; Razavi, B.S.; Kuzyakov, Y. Effect of land use and management practices onmicrobial biomass and enzyme activities in subtropical top-and sub-soils. Appl. Soil Ecol. 2017, 113, 22-28.

44. Paz-Ferreiro, J.; Gascó, G.; Gutiérrez, B.; Méndez, A. Soil biochemical activities and the geometric mean ofenzyme activities after application of sewage sludge and sewage sludge biochar to soil. Biol. Fertil. Soils2012, 48, 511-517.

45. Anderson, T.-H.; Domsch, K.H. The metabolic quotient for $\mathrm{CO} 2$ (qCO2) as a specific activity parameter toassess the effects of environmental conditions, such as ph, on the microbial biomass of forest soils. Soil Biol.Biochem. 1993, 25, 393-395.

46. Ramírez, M.; López-Piñeiro, A.; Peña, D.; Nunes, J.R.; Albarrán, Á.; Muñoz, A.; Gama, J.; Loures, L. Seasonaland interannual fluctuation of the microbial soil community in a maize field under long-term conservationagriculture management. Sustainability 2017, 9,778

47. Cherubin, M.R.; Karlen, D.L.; Franco, A.L.C.; Cerri, C.E.P.; Tormena, C.A.; Cerri, C.C. A Soil ManagementAssessment Framework (SMAF) evaluation of Brazilian sugarcane expansion on soil quality. Soil Sci. Soc.Am. J. 2016, 80, 215-226.

48. Moreira, F.M.S. Bacterias formadoras de nódulos en leguminosas. In Manual de Biología de Suelos Tropicales:Muestro y Caracterización de la Biodiversidad Bajo Suelo; Instituto Nacional de Ecologiía: México city, Mexico,2012; pp. 177-216.

49. GROW Observatory GROW Food. GROW Soil. GROW Science. Available online: https://growobservatory.org/ (accessed on 31 October 2019).

50. Power, A.G. Ecosystem services and agriculture: Tradeoffs and synergies. Philos. Trans. R. Soc. B Biol. Sci.2010, 365, 2959-2971.

51. Viana, R.M.; Ferraz, J.B.S.; Neves, A.F.; Vieira, G.; Pereira, B.F.F. Soil quality indicators for different restorationstages on Amazon rainforest. Soil Tillage Res. 2014, 140, 1-7

\section{Keywords}

Biological quality of the soil; Biological indicators; Bioindicators; Soil quality; Ecuadorian Amazon; Biological quality indicators; Soil quality index 